\title{
Friedreich's ataxia
}

\section{A clinical review with neurophysiological and echocardiographic findings}

\author{
R S ACKROYD, J A FINNEGAN, AND S H GREEN
}

Institute of Child Health, Birmingham

SUMMARY In a review of twelve cases of Friedreich's ataxia, the important criteria for early diagnosis were identified. Clinical signs included absent tendon reflexes, ataxic gait, and a positive Romberg test. Nerve conduction velocities showed absent or severely slowed sensory conduction, with normal motor conduction. In addition, echocardiographic changes of symmetrical hypertrophic cardiomyopathy were found.

The original description of Friedreich's ataxia ${ }^{1-3}$ was of a familial progressive ataxia, with onset around puberty, loss of tendon reflexes, loss of posterior column sensation, and later cardiomyopathy. In the past considerable confusion arose over a number of conditions with clinical features overlapping Friedreich's ataxia, including the Charcot-Marie-Tooth, ${ }^{4,5}$ Roussey-Lévy, ${ }^{6}$ and Dejerine-Sottas $^{7}$ syndromes. The introduction of electro-physiological techniques led to Dyck's classification (based on nerve conduction velocity) of 'hereditary motor and sensory neuropathies' (HMSN), ${ }^{8}$ but although this has led to some resolution of diagnostic problems, confusion has continued and our aim was to elucidate the diagnostic features of Friedreich's ataxia.

Friedreich's ataxia has been widely studied in adults during the past 20 years. The Quebec cooperative study, in a clinical review of 50 cases, produced a number of specific criteria they considered essential for diagnosis. ${ }^{9}$ Harding, in a review of 150 cases, ${ }^{10}$ while agreeing with the Quebec study that ataxia of all limbs and absent tendon reflexes were mandatory for the clinical diagnosis of Friedreich's ataxia, found that rigid criteria could not always be applied, particularly in early childhood when the clinical picture may not be fully developed.

A clinical diagnosis must now be supported with nerve conduction studies. In Friedreich's ataxia there is substantial evidence that the motor conduction velocity is normal or slightly reduced, and that sensory conduction is absent or severely reduced. ${ }^{11-16}$

Friedreich's ataxia in children has received little attention and, except for one study, ${ }^{14}$ the clinical picture has been based on adults. Because of this and the apparent confusion over diagnosis we studied a group of children falling into the broad category of spinocerebellar degeneration and peripheral neuropathies. We report here the findings in our cases with Friedreich's ataxia.

\section{Patients and methods}

All cases known to the Children's Hospital in Birmingham with a diagnosis of pes cavus, peripheral neuropathy, Friedreich's ataxia, hereditary spastic paraparesis, and hereditary cerebellar ataxia were reviewed. A total of 51 patients were identified and were reclassified as follows:

(1) Hereditary motor and sensory neuropathy (23).

(2) Friedreich's ataxia (12).

(3) Hereditary spastic paraparesis (14).

(4) Other (2).

The criteria for diagnosis of Friedreich's ataxia were:

Absent tendon reflexes.

Ataxia of all limbs.

Normal motor conduction velocity.

Absent or severely reduced sensory conduction velocity.

Each child had a detailed historical and clinical review.

Electrophysiological studies were performed with a Medilec MS6 system at a thermostatically controlled room temperature. Standard techniques were used, with a stimulus duration of $0.1 \mathrm{~ms}$ and all responses were supramaximal. ${ }^{17}$ Sensory action 
potentials were averaged and latencies measured to the onset of the potential-amplitudes were measured peak to peak. The normality, or otherwise, of the conduction velocity was assessed after consideration of the patient's age. ${ }^{18} \mathrm{~A}$ combination of lateral popliteal, median, ulnar, sural, and radial nerves were studied.

Electromyography was performed with a concentric needle electrode. Cardiac status was assessed clinically. An M mode echocardiogram was recorded in all cases. A standard 12 lead electrocardiogram was recorded. Detailed echocardiographic findings are to be reported separately.

\section{Results}

Presentation. Details of presentation are given in Table 1. All children studied were still at school. The mean age of onset of symptoms was 5.8 years. Eight children were seen within four years of onset of the symptoms. The main presenting complaint was abnormal gait (11 of 12 patients). One child presented to the cardiologist with fainting, and one also had pes cavus deformity.

Before review the diagnosis was correct in 5 of 12 children. It was common for the diagnosis to have been delayed and often alternative diagnoses had been reached. Slow progression was usually present, but several patients had had static periods for up to one year.

Clinical neurology. Table 2 shows that all the children had absent tendon reflexes in the legs, ataxic gait, finger-nose and heel-toe incoordination, and a positive Romberg test. Generalised lower limb weakness and wasting was common (11 of 12 patients), while the upper limbs were relatively

Table 1 Age distribution and presenting features in 12 children with Friedreich's ataxia

\begin{tabular}{ll}
\hline Boys & 6 \\
Girls & 6 \\
Age at review (years) & $6-16$ \\
Range & $10 \cdot 1$ \\
Mean & \\
Age at onset of symptoms (years) & $3-9$ \\
Range & $5 \cdot 8$ \\
Mean & $1-10$ \\
Duration of disease (years) & $4 \cdot 7$ \\
Range & \\
Mean & $3 \cdot 2$ \\
Period of progression of symptoms (years) & \\
Mean & 11 \\
Presenting symptoms & 3 \\
Abnormal gait & 1 \\
Writing difficulty & 1 \\
Leg pain & 1 \\
Foot deformity & \\
\hline
\end{tabular}

Table 2 Clinical signs in 12 children with Friedreich's ataxia

\begin{tabular}{|c|c|}
\hline Signs & No \\
\hline \multicolumn{2}{|l|}{ Cerebellar } \\
\hline Ataxic gait & 12 \\
\hline Finger-nose incoordination & 12 \\
\hline Heel-toe incoordination & 12 \\
\hline Dysarthria & 9 \\
\hline Nystagmus & 3 \\
\hline \multicolumn{2}{|l|}{ Tendon reflexes } \\
\hline Lower limb & 12 \\
\hline Absent & - \\
\hline \multicolumn{2}{|l|}{ Upper limb } \\
\hline \multirow{2}{*}{$\begin{array}{l}\text { Absent } \\
\text { Reduced }\end{array}$} & 10 \\
\hline & 2 \\
\hline \multicolumn{2}{|l|}{ Plantar reflex } \\
\hline Extensor & 5 \\
\hline Normal & 7 \\
\hline \multicolumn{2}{|l|}{ Sensory signs } \\
\hline Romberg test positive & 12 \\
\hline Vibration & \\
\hline Reduced & 8 \\
\hline \multirow{2}{*}{$\begin{array}{l}\text { Normal } \\
\text { Joint position }\end{array}$} & 4 \\
\hline & \\
\hline Reduced & 2 \\
\hline \multirow{2}{*}{ Normal } & 10 \\
\hline & - \\
\hline \multirow{2}{*}{ Muscle tone } & \\
\hline & 8 \\
\hline Reduced & 4 \\
\hline \multicolumn{2}{|l|}{ Muscle weakness } \\
\hline \multirow{2}{*}{$\begin{array}{l}\text { Upper limb } \\
\text { Lower } \operatorname{limb}\end{array}$} & 4 \\
\hline & 11 \\
\hline \multicolumn{2}{|l|}{ Muscle wasting } \\
\hline \multirow{2}{*}{$\begin{array}{l}\text { Upper limb } \\
\text { Lower limb }\end{array}$} & 5 \\
\hline & 11 \\
\hline \multicolumn{2}{|l|}{ Skeletal } \\
\hline Mild & 6 \\
\hline Pes cavus Moderate & 3 \\
\hline Severe & 1 \\
\hline Scoliosis & 4 \\
\hline
\end{tabular}

spared. Dysarthric speech was also present (9 of 12 patients), although this was not always recognised by the family.

Sensory signs may be uncertain in young children, but vibration sense was reduced in 8 of 12 . Loss of joint position sense only affected two patients. There were no children with loss of pain, touch, or temperature sensations, although children often complained of having cold feet. Extensor plantars were present in only 5 of 12 children. Occular signs were minimal with only three children having mild horizontal nystagmus, and all fundi were normal.

Neurophysiology. Eleven children had had nerve conduction velocities measured (Table 3 ), and one (case 16) declined investigation. All had motor conduction velocity in the normal or near normal 
Table 3 Neurophysiological and cardiological findings in 12 children with Friedreich's ataxia

\begin{tabular}{|c|c|c|c|c|c|c|c|c|}
\hline \multirow{2}{*}{$\begin{array}{l}\text { Case } \\
\text { No }\end{array}$} & \multirow{2}{*}{$\begin{array}{l}\text { Age NCV } \\
\text { measured } \\
\text { (years) }\end{array}$} & \multicolumn{2}{|c|}{ Motor nerve conduction } & \multicolumn{2}{|c|}{ Sensory nerve conduction } & \multirow{2}{*}{$\begin{array}{l}\text { Electro- } \\
\text { myography }\end{array}$} & \multirow{2}{*}{$\begin{array}{l}\text { Echo- } \\
\text { cardiography }\end{array}$} & \multirow{2}{*}{$\begin{array}{l}\text { Electro- } \\
\text { cardiography }\end{array}$} \\
\hline & & $\begin{array}{l}\text { Nerve } \\
\text { tested }\end{array}$ & $\begin{array}{l}\text { Velocity } \\
(\mathrm{m} / \mathrm{sec})\end{array}$ & $\begin{array}{l}\text { Nerve } \\
\text { tested }\end{array}$ & $\begin{array}{l}\text { Velocity } \\
(\mathrm{m} / \mathrm{sec})\end{array}$ & & & \\
\hline 2 & 12 & $\begin{array}{l}\text { Lateral } \\
\text { popliteal }\end{array}$ & 34 & $\begin{array}{l}\text { Median and } \\
\text { sural }\end{array}$ & Absent & Normal & Abnormal & Abnormal \\
\hline 9 & 5 & $\begin{array}{l}\text { Lateral } \\
\text { popliteal }\end{array}$ & 37 & $\begin{array}{l}\text { Median and } \\
\text { sural }\end{array}$ & Absent & Normal & Abnormal & Abnormal \\
\hline 11 & 6 & $\begin{array}{l}\text { Lateral } \\
\text { popliteal }\end{array}$ & $\begin{array}{l}49 \\
\text { left } 43\end{array}$ & $\begin{array}{l}\text { Median and } \\
\text { sural }\end{array}$ & Absent & Normal & Abnormal & Normal \\
\hline 29 & 9 & $\begin{array}{l}\text { Lateral } \\
\text { popliteal }\end{array}$ & $\begin{array}{l}\text { Normal } \\
\text { amplitude and } \\
\text { latency-no } \\
\text { velocity } \\
\text { recorded }\end{array}$ & $\begin{array}{l}\text { Median and } \\
\text { sural }\end{array}$ & Absent & NR & Abnormal & Abnormal \\
\hline 30 & 9 & $\begin{array}{l}\text { Lateral } \\
\text { popliteal }\end{array}$ & & $\begin{array}{l}\text { Median and } \\
\text { sural }\end{array}$ & Absent & Normal & Abnormal & Normal \\
\hline 40 & 7 & $\begin{array}{l}\text { Lateral } \\
\text { popliteal }\end{array}$ & 42 & $\begin{array}{l}\text { Median and } \\
\text { sural }\end{array}$ & $\begin{array}{l}\text { Absent } \\
\text { Right } 15 \\
\text { left } 14\end{array}$ & Normal & Abnormal & Abnormal \\
\hline 43 & 16 & $\begin{array}{l}\text { Lateral } \\
\text { popliteal }\end{array}$ & 37 & $\begin{array}{l}\text { Median and } \\
\text { sural }\end{array}$ & Absent & NR & Abnormal & Abnormal \\
\hline 44 & 6 & $\begin{array}{l}\text { Lateral } \\
\text { popliteal }\end{array}$ & 37 & $\begin{array}{l}\text { Median and } \\
\text { sural }\end{array}$ & Absent & Normal & Abnormal & Abnormal \\
\hline 4 & 10 & $\begin{array}{l}\text { Lateral } \\
\text { popliteal }\end{array}$ & 44 & $\begin{array}{l}\text { Median and } \\
\text { ulnar }\end{array}$ & Absent & Normal & Abnormal & Abormal \\
\hline 3 & 10 & Median & 53 & $\begin{array}{l}\text { Median and } \\
\text { radial }\end{array}$ & Absent & NR & Abnormal & Abnormal \\
\hline 20 & 10 & Median & 55 & $\begin{array}{l}\text { Median, } \\
\text { ulnar, and } \\
\text { radial }\end{array}$ & Absent & $\begin{array}{l}\text { Mild motor } \\
\text { neuropathy }\end{array}$ & Abnormal & Abnormal \\
\hline 16 & NR & NR & NR & NR & NR & NR & Abnormal & Abnormal \\
\hline
\end{tabular}

NR $=$ Not recorded

range. Sënsory conduction was absent in 10 , and severely reduced in one (case 40). Electromyography was undertaken in six patients-five were normal and one showed mild neuropathic changes.

Cardiac findings. At clinical examination 9 children had abnormal signs, 7 with systolic murmurs and two with a jerky upstroke in the pulse (Table 3). Ten of 12 children had abnormal electrocardiograms (ECG). (Table 4). Five had evidence of ventricular hypertrophy and 6 had $T$ wave changes, mainly in the infero-lateral leads.

All 12 children had an abnormal echocardiograph (ECHO). When the predicted values for age and weight were taken into account the ECHO showed a statistically significant difference from that of normal controls. The abnormality seen was symmetrical, concentric, hypertrophic cardiomyopathy.

Skeletal problems. Pes cavus deformity was common (10 of 12 cases), but was not enough alone to produce abnormal gait, and in only one child was it severe. Early cases had little or no foot deformity (Table 2). Scoliosis was uncommon, with only 4 of 12 children affected, of whom three required bracing.
Genetics. Where there was a family history this supported a recessive inheritance. Seven of 12 children had a family history of Friedreich's ataxia. Two pairs of siblings were included (cases 29 and 30; 9 and 44). One further child (case 20) had a sibling who had died of cardiomyopathy with undiagnosed neurological symptoms, and one (case 43) had a brother and cousin living abroad who probably had Friedreich's ataxia. There was one boy with an affected second cousin (case 40) but no other known

Table 4 Cardiac findings in 12 children with Friedreich's ataxia

\begin{tabular}{lc}
\hline Cardiac signs & \\
Systolic murmur & 7 \\
Abnormal pulse & 2 \\
Electrocardiogram & \\
Abnormal & 10 \\
LVH & 4 \\
RVH & 1 \\
T wave inversion & 6 \\
R axis deviation & 2 \\
R bundle branch block & 1 \\
Echocardiogram & \\
Abnormal & 12 \\
Symmetrical cardiomyopathy & 12 \\
\hline
\end{tabular}


relative was affected and there was no consanguinity. Two Asian children had Friedreich's ataxia; both were from consanguinous cousin marriages, but in only one (case 43) was a sibling also affected.

\section{Discussion}

This report highlights the diagnostic criteria which, in childhood, will lead to an early and accurate diagnosis of Friedreich's ataxia. The varied initial diagnoses and the delay in reaching a final diagnosis reflect the lack of knowledge and published reports on Friedreich's ataxia in children. It is common for these cases to present to orthopaedic surgeons. The early age of onset means that this diagnosis should be considered in the preschool and primary school aged child who develops gait abnormalities.

Our report includes 8 of 12 children seen within four years of the onset of symptoms, and is probably a true reflection of early clinical signs. The clinical signs agree with those of Harding ${ }^{10}$ - absent tendon reflexes, ataxic gait, and incoordinate movementsbut we also found a positive Romberg test in all cases. In addition, the children had a strikingly similar appearance with generalised wasting of muscle bulk. The Quebec criteria for diagnosis ${ }^{9}$ would not be met in this series, and if followed strictly, would have led to considerable delay in diagnosis. In particular, loss of vibration and joint position sense was not noticeable and extensor plantar responses were often absent. Progression of symptoms was not continuous, some children had periods as long as a year with little clinical change. The presence of brisk reflexes should exclude the diagnosis of Friedreich's ataxia. There are several recessive conditions which mimick Friedreich's ataxia and in which brisk reflexes are present. ${ }^{19-21}$

Nerve conduction studies (both motor and sensory) are essential to make a diagnosis of Friedreich's ataxia. Our findings confirm the previous reports of severely slowed or absent sensory conduction with normal motor conduction velocity. ${ }^{11-16}$ Where nerve conduction studies are normal, but clinical signs strongly suggest a diagnosis of Friedreich's ataxia, spinal evoked responses may be helpful. ${ }^{10}$

ECHO changes have not been reported in a large group of children before. The detailed changes will be published separately, but it is highly significant that all typical cases of Friedreich's ataxia should have had an abnormal ECHO. Changes seen were of symmetrical, concentric, hypertrophic cardiomyopathy. We believe that this is an important diagnostic aid. It has been suggested that Fried- reich's ataxia should be suspected in children with unexplained cardiomyopathy ${ }^{22}$ and diagnosis might be reached before the onset of overt neurological symptoms. ${ }^{23}$ Our findings would support this suggestion as an abnormal ECHO was present even in the youngest child at the age of 5 years. ECHO studies in adult patients have also found symmetrical, hypertrophic cardiomyopathy. ${ }^{23-25}$ Weiss, in a series of 17 adults, found only two with symmetrical changes, however, while 8 had asymmetric cardiomyopathy. ${ }^{26}$ ECG changes were common, but did not help in diagnosis. Cardiomyopathy has been associated with other causes of peripheral neuropathy, ${ }^{27,28}$ and the possibility of Refsum's disease should be considered if there is severe loss of motor as well as sensory conduction velocity. ${ }^{29}$

Skeletal abnormalities may not have developed in children and it is known that severe scoliosis is rare before symptoms have been present for 6 years. ${ }^{9}$ The monitoring and detection of scoliosis is important, as early intervention may prevent severe deformity, particularly during the pubertal growth spurt. The presence of pes cavus is clearly not essential for diagnosis.

A family history of Friedreich's ataxia may lead to early diagnosis, as it did in one of our children (case 44). Nerve conduction studies can probably predict whether siblings are affected, but this has not been reported. Consanguinity was not an important factor. Two children in the study were Asian, confirming that this racial group may be affected.

\section{Conclusion}

Friedreich's ataxia is a clearly defined disease in which the early clinical signs include ataxia of gait, areflexia, and a positive Romberg test. Abnormal sensory nerve conduction is always present with near normal motor conduction velocities. In addition, ECHO may show evidence of cardiomyopathy. It is particularly important that Friedreich's ataxia should not be diagnosed in the absence of typical findings, as this makes later rediagnosis difficult. Early accurate diagnosis is possible, relieves uncertainty in the family, and allows appropriate supportive management. If advances are made leading to possible treatments, these will probably be in early cases and will be appropriate to prevent neurological damage.

We thank the Centenary Fund of the Children's Hospital, Birmingham for financial support, Dr J de Giovanni and Dr E Silove for the cardiac investigations, and Professor B Hagberg for helpful advice on the paper. Secretarial help was given by Miss Helen Miles and Mrs Kaye Evans. 


\section{References}

${ }^{1}$ Friedreich N. Ueber degenerative atrophie der spinale hinterstränge. Virchows Archiv (Pathol Anat) 1863;26:391-419, 43359;27:1-26.

2 Friedreich $\mathrm{N}$. Über ataxie mit besonderer berücksichtigung der herëditären formen. Virchows Archiv (Pathol Anat) 1876;68:145-245.

${ }^{3}$ Friedreich N. Über ataxie mit besonderer berücksichtigung der herëditären formen. Virchows Archiv (Pathol Anat) 1877;70:140-52.

${ }^{4}$ Charcot JM, Marie P. Sure une forme particuliere d'atrophie musculaire progressive souvent familiale, debutant pare les pieds at les james et atteignant plus tard les mains. Rev Med Intern 1886;6:97-138.

5 Tooth HH. The peroneal type of progressive muscular atrophy. London: HK Lewis, 1886.

6 Roussy G, Lévy G. Sept cas d'une maladre familiale particulière: troubles de la marche, pieds bots et aréfléxie tendinense genéralisée, avec accessoirment légère maladress des mains. Rev Neurol (Paris) 1926;33:427-50.

7 Dejerine J, Sottas J. Sur las nevrite interstitielle, hypertrophique et progressive de l'enfante. Comptes Rendues de la Societé de Biologie 1893; 9th series, vol. 5, pt 2.

8 Dyck PJ. Inherited neuronal degeneration and atrophy affecting peripheral motor, sensory and autonomic neurons. In: Dyck PJ, Thomas PK, Lambert EH, eds. Peripheral neuropathy Vol II. Philadelphia: WB Saunders, 1975:825-67.

${ }^{9}$ Geoffroy G, Barbeau A, Breton G, et al. Clinical description and roentgenologic evaluation of patients with Friedreich's ataxia. Can J Neurol Sci 1976;3:279-86.

10 Harding AE. Friedreich's ataxia: a clinical and genetic study of 90 families with an analysis of early diagnostic criteria and intrafamilial clustering of clincal features. Brain 1981;104: 589-620.

11 McLeod JG. Electrophysiological and histological studies in patients with Friedreich's ataxia. Electroencephalogr Clin Neurophysiol 1969;27:723.

12 McLeod JG. An electrophysiological amd pathological study of peripheral nerves in Friedreich's ataxia. $J$ Neurol Sci 1971;12:333-49.

$13 \mathrm{Oh} \mathrm{SJ}$, Halsey JH, Jr. Abnormality in nerve potentials in Friedreich's ataxia. Neurology 1973;23:52-4.

14 Dunn HG. Nerve conduction studies in children with Friedreich's ataxia and ataxia telangiectasia. Dev Med Child Neurol 1973;15:324-37.

15 Peyronnard JM, Lapointe L, Bouchard JP, Lamentagne A, Lemieux B, Barbeu A. Nerve conduction studies and electromyography in Friedreich's ataxia. Can J Neuro Sci 1976;3,313-7.
16 Jones SJ, Baraitser M, Halliday AM. Peripheral and central somatosensory nerve conduction defects in Friedreich's ataxia. J Neurol Neurosurg Psychiatry 1980;43:495-503.

17 Smorto MP, Basmajian JV. Clinical electroneurophysiology. Baltimore: Williams \& Wilkins, 1972.

18 Gamstorp I. Normal conduction velocity of ulnar, median and peroneal nerves in infancy, childhood and adolescence. Acta Paediatr Scand (Suppl) 1983;146:68.

19 Bouchard JP, Barbeau A, Bouchard R, Bouchard RW. Autosomal recessive spastic ataxia of Charlevoix Saguenay. Can J Neurol Sci 1978;5:61-9.

20 Bouchard JP, Barbeau A. Bouchard R, Bouchard RW. Electromyography and nerve conduction studies in Friedreich's ataxia and autosomal recessive spastic ataxia of Charlevoix Saguenay. Can J Neurol Sci 1979;6:185-9.

21 Harding AE. Early onset of cerebellar ataxia with retained tendon reflexes-a clinical and genetic study of a disorder distinct from Friedreich's ataxia. J Neurol Neurosurg Psychiatry 1981;44:503-8.

22 Berg RA, Kaplan AM, Jarrett PB, Molthan ME. Friedreich's ataxia with acute cardiomyopathy. Am J Dis Child 1980;134: 390-3.

23 Sutton MG St J, Olukotun A, Tajik AJ, Lovett JL, Giuliani ER. Left ventricular function in Friedreich's ataxia, an echocardiographic study. Br Heart $J$ 1980;44:309-16.

24 Pasternac A, Król R, Petitclerc R, Harvey C, Anderman E, Barbeau A. Hypertrophic cardiomyopathy in Friedreich's ataxia: symmetric or asymmetric? Can J Neurol Sci 1980;7: 379-82.

25 Gattiker HF, Davignon A, Bozio A, et al. Echocardiographic findings in Friedreich's ataxia. Quebec co-op study. Can J Neurol sci 1976;3:329-32.

26 Weiss E, Kronzon I, Winer HE, Berger AR. Echocardiographic observations in patients with Friedreich's ataxia. Am J Med Sci 1981;282:136-40.

27 Lascelles RG, Baber IA, Thomas PK. Hereditary polyneuropathy of Roussy Levy type with associated cardiomyopathy. Guy's Hospital Reports 1970;119:253-62.

28 Liu HM, Gumbinas M. Axonal filamentous spheroids, associated with carrdiomyopathy with targetoid fibres. Neurology 1974;24:547-54.

29 Refsum S. Heredopathia ataetica polyneuritiformis (Refsum's disease): clinical and genetic aspects of Refsum's disease. In: Dyck PJ, Thomas PK, Lambert EH, eds. Peripheral neuropathy Vol II. Philadelphia: WB Saunders, 1975:868-90.

Correspondence to Dr R S Ackroyd, The Children's Hospital, Battledown, Cheltenham, Gloucestershire.

Received 12 October 1983 